\title{
DESAIN APLIKASI INTERAKTIF MODEL PEMBELAJARAN AKUNTANSI BAGI SISWA SEKOLAH MENENGAH KEJURUAN
}

\author{
${ }^{1}$ Chitra Santi \\ Program Studi Akuntansi Fakultas Ekonomi Universitas Widya Kartika Surabaya \\ E-mail: chitrasanti1@gmail.com \\ ${ }^{2}$ Melvie Paramitha \\ Program Studi Akuntansi Fakultas Ekonomi Universitas Widya Kartika Surabaya \\ Email : melvieparamitha24@gmail.com \\ ${ }^{3}$ Minny Elisa Yanggah \\ Program Studi Pendidikan Bahasa Mandarin Fakultas Sastra dan Pendidikan Bahasa \\ Universitas Widya Kartika Surabaya \\ Email : minnyelisa@widyakartika.ac.id
}

\begin{abstract}
The rapid development of technology, will have an impact on learning methods in schools. The learning method will begin to shift from manual methods to learning methods using applications / software. Schools are required to be able to create appropriate learning methods and produce graduates who are proficient in operating technology such as making financial reports using software as a means of accounting knowledge. The purpose of this study is to design a technology-based accounting learning model to facilitate and motivate accounting learning for vocational students. The approach of this research is an explorative research of a technical applicative nature with a multidisciplinary approach which is the approach of the fields of accounting and technology. Data collection methods in this study include documentation, observation, and interviews. Design interactive applications using Macromedia Flash Player 8. The results of the study provide an interactive application of accounting learning models called Accounters. This application consists of three main menus namely Material, Quiz, and Hangman (game). Therefore, the Accounters application makes it easy for students in vocational schools to better understand accounting, so they are able to make financial reports for companies when they work later. And able to increase student motivation in accounting.
\end{abstract}

Keywords: learning media, accounting, accounters

\begin{abstract}
ABSTRAK
Perkembangan teknologi yang semakin pesat, akan memberi dampak pada metode pembelajaran di sekolah. Metode pembelajaran tersebut akan mulai bergeser dari cara yang manual menjadi metode pembelajaran menggunakan aplikasi/software. Sekolah dituntut untuk mampu menciptakan metode pembelajaran yang tepat serta menghasilkan lulusan yang mahir mengoperasikan teknologi seperti membuat laporan keuangan dengan menggunakan suatu software sebagai sarana pendalaman ilmu akuntansi.Tujuan penelitian ini adalah mendesain model pembelajaran akuntansi berbasis teknologi untuk mempermudah dan memotivasi belajar akuntansi bagi siswa


SMK. Pendekatan penelitian ini adalah penelitian eksploratif yang bersifat teknis aplikatif dengan pendekatan multidisipliner yaitu pendekatan bidang ilmu akuntansi dan teknologi. Metode pengumpulan data dalam penelitian ini meliputi dokumentasi, observasi, dan wawancara. Desain aplikasi interaktif menggunakan macromedia flash player 8. Hasil penelitian memberikan sebuah aplikasi interaktif model pembelajaran akuntansi yang dinamakan Accounters. Aplikasi ini terdiri dari tiga menu utama yaitu Materi, Quiz, dan Hangman (permainan). Oleh karena itu, dengan aplikasi Accounters ini mempermudah siswa di SMK untuk lebih memahami tentang akuntansi, sehingga mampu membuat laporan keuangan bagi perusahan saat mereka bekerja nantinya. Serta mampu meningkatkan motivasi belajar siswa dalam ilmu akuntansi.

Kata kunci: media pembelajaran, akuntansi, accounters

\section{PENDAHULUAN}

Di Era serba teknologi saat ini, setiap individu dituntut untuk mahir dalam mengoperasikansebuah teknologi baik dalam rutinitas setiap hari maupun kegiatan di dalam Perusahaan. Olehkarena itu, di dunia yang serba modern saat ini, banyak teknologi-teknologi mutakhir yang terciptauntuk peningkatan kemampuan sumber daya manusia, begitupula dalam hal pendidikan. Saat ini,pendidikan adalah sarana utama dalam meraih keuntungan baik itu secara financial maupun dalamhal intelektual. Pendidikan juga menjadi tanggung jawab pemerintah dan memerlukan perhatian

khusus dalam pengembangannya. Hal ini tertuang pada Undang-Undang Dasar 1945 yaknimencerdaskan kehidupan bangsa.

Saat ini, sekolah vokasi berusaha untuk mampu menciptakan metode pembelajaran yangmenarik dan tepat guna menghasilkan lulusan yang mahir mengoperasikan teknologi sepertimembuat laporan keuangan dengan menggunakan suatu software. Sekolah vokasi mulaimengembangkan minat siswa dalam berbagai hal seperti ketrampilan, kemampuan bahasa asingserta terutama dalam mempelajari tentang akuntansi. Karena di dalam dunia bisnis, Perusahaanmembutuhkan banyak tenaga kerja akuntan dalam membuat laporan keuangan. Oleh karena itu,dengan aplikasi Accounters ini diharapkan mempermudah siswa di Sekolah untuk lebih memahamitentang akuntansi, sehingga mampu membuat laporan keuangan bagi Perusahan saat merekabekerja nantinya. Serta diharapkan mampu meningkatkan motivasi belajar siswa akan akuntansi. 
Oleh karena itu, dari femonena yang terjadi diatas, maka peneliti akan membuatPengembangan Model Pembelajaran Akuntansi dengan Aplikasi Interaktif untukmeningkatkan Kemampuan dan Motivasi Siswa pada Sekolah Vokasi. Penelitian ini bertujuan untuk mendesain aplikasi interaktif model pembelajaran akuntansi berbasis teknologi bagi siswa SMK.

\section{Rumusan Masalah}

Rumusan masalah dalam penelitian ini adalah sebagai berikut:

Bagaimana desain aplikasi interaktif untuk model pembelajaran akuntansi bagi siswa Sekolah Menengah Kejuruan (SMK)?

\section{LANDASAN TEORI}

\section{Akuntansi}

Menurut Reeve (2009) adalah suatu sistem informasi yang menyediakan laporan untukpara pemangku kepentingan mengenai aktivitas dan kondisi ekonomi perusahaan. Akuntansi adalah sistem informasi yang menghasilkan laporan kepada pihak-pihak yang berkepentingan mengenai aktivitas ekonomi dan kondisi perusahaan. Warsono, dkk (2009:2) menjelaskan akuntansi adalah proses sistematis untuk mengolah transaksimenjadi informasi keuangan yang bermanfaat bagi para penggunanya.

\section{Fungsi Media dalam Pembelajaran}

Fungsi media pembelajaran adalah untuk membuat siswa tertarik dan dapatmeningkatkan motivasi siswa dalam mempelajari sesuatu. Sutikno (2013:106) jugamenjelaskan bahwa fungsi media dalam proses pembelajaran adalah menarik perhatiansiswa, membuat pembelajaran lebih komunikatif, meningkatkan gairah belajar siswa, sertameningkatkan kadar keaktifan siswa dalam kegiatan pembelajaran.

\section{Minat Belajar}

Minat merupakan suatu keinginan seseorang untuk melakukan suatu perilakutertentu.

Salah satu pendukung yang berpengaruh dalam memperoleh prestasi dalambelajar adalah minat belajar. Seseorang memiliki minat terhadap subjek tertentu cenderunguntuk memberikan perhatian yang lebih besar terhadap subjek tertentu. Seels \& Richey (2014) membagi media pembelajaran dalam empat kelompok, yaitu: 
a. Media hasil teknologi cetak

Media hasil teknologi cetak adalah cara untuk menghasilkan ataumenyampaikan materi melalui proses pencetakan mekanis atau fotografis.Kelompok media hasil teknologi cetak meliputi teks, grafik, foto, danrepresentasi fotografik. Materi cetak dan visual merupakan pengembangan danpenggunaan kebanyakan materi pengajaran lainnya. Teknologi inimenghasilkan materi dalam bentuk salinan tercetak, contohnya buku teks,modul, majalah, hand-out, dan lain-lain.

b. Media hasil teknologi audio-visual

Media hasil teknologi audio-visual menghasilkan atau menyampaikan materidengan menggunakan mesin-mesin mekanis dan elektronik untuk menyajikanpesan-pesan audio dan visual. Contohnya proyektor film, televisi, video, dansebagainya.

c. Media hasil teknologi berbasis komputer

Media hasil teknologi berbasis komputer merupakan cara menghasilkan ataumenyampaikan materi dengan menggunakan sumber-sumber yang berbasismikro-prosesor. Berbagai jenis aplikasi teknologi berbasis komputer dalampengajaran umumnya dikenal sebagai computer-assisted instruction(pengajaran dengan bantuan komputer).

d. Media hasil teknologi gabungan

Media hasil teknologi gabungan adalah cara untuk menghasilkan ataumenyampaikan materi yang menggabungkan beberapa bentuk media yangdikendalikan oleh komputer. Perpaduan beberapa teknologi ini dianggap teknikyang paling canggih. Contohnya: teleconference.

Penelitian mengenai desain aplikasi interaktif dalam membantu proses belajarmengajar telah dilakukan oleh beberapa peneliti. Berikut beberapa penelitian terdahulu yang menjadi referensi dalam penelitian ini yaitu: 
Tabel 1. Penelitian Terdahulu sebagai Referensi

\begin{tabular}{|c|c|c|c|}
\hline No & Peneliti/Tahun & Judul Penelitian & Hasil Penelitian \\
\hline 1. & Suhita (2016) & $\begin{array}{l}\text { Pengembangan Media Pembelajaran } \\
\text { Akuntansi Berbasis Film Dokumenter } \\
\text { Untuk Meningkatkan Motivasi Belajar } \\
\text { Siswa Kelas Xii Ips } 3 \text { SMAN Iseyegan } \\
\text { Tahun Ajaran 2015/2016 }\end{array}$ & $\begin{array}{l}\text { Media pembelajaran akuntangi berbasis } \\
\text { film dokumenter terbukti mampu } \\
\text { meningkatkan motivasi belajar dengan } \\
\text { gain score sebesar } 0,44 \text { yang termasuk } \\
\text { dalam kategori gedang. }\end{array}$ \\
\hline 2 & Dewi (2016) & $\begin{array}{l}\text { Pengembangan Komik Akuntansi } \\
\text { Sebagai Media Pembelajaran Akuntansi } \\
\text { Pada Materi Jurnal Penyesuaian Untuk } \\
\text { Siswa Kelas XI IPS SMA Negeri } 1 \\
\text { Imogiri Tahun Ajaran 2015/2016 }\end{array}$ & $\begin{array}{l}\text { Pengembangan media pembelajaran } \\
\text { Akuntansi berbentuk komik pada materi } \\
\text { jurnal penyeguaian untuk siswa SMA } \\
\text { digunakan sebagai media pembelajaran } \\
\text { yang menarik. Media Komik sangat layak } \\
\text { digunakan sebagai media pembelajaran } \\
\text { Akuntansi SMA kelas XI IPS. }\end{array}$ \\
\hline 3 & $\begin{array}{l}\text { Ramadhani, } \\
\text { Sentosa, dan } \\
\text { Ngadiman (2013) }\end{array}$ & $\begin{array}{l}\text { Upaya Peningkatan Kualitas } \\
\text { Pembelajaran Akuntansi Melalui } \\
\text { Penerapan Model Pembelajaran } \\
\text { Berbasis Projek (Project Based } \\
\text { Learning) }\end{array}$ & $\begin{array}{l}\text { Penerapan model pembelajaran berbasis } \\
\text { projek (Project Based Learning) masih } \\
\text { terdapat hambatan dalam pembelajaran } \\
\text { akuntansi. Hambatan-hambatan dalam } \\
\text { pembelajaran akuntansi adalah gebagai } \\
\text { berikut: (1) guru belum sepenuhnya paham } \\
\text { dengan model pembelajaran yang } \\
\text { diterapkan, sehingga guru perlu } \\
\text { mempelajari model pembelajaran }\end{array}$ \\
\hline 4 & $\begin{array}{l}\text { Usyanti dan } \\
\text { Susanti (2015) }\end{array}$ & $\begin{array}{l}\text { Pengembangan Media Pembelajaran } \\
\text { Akuntansi Berbasis Multimedia } \\
\text { Interaktif Pada Materi Rekonsiliasi } \\
\text { Bank Untuk Kelas XI Akuntansi SMK } \\
\text { Negeri I Lamongan }\end{array}$ & $\begin{array}{l}\text { Media pembelajaran akuntangi berbasis } \\
\text { multimedia interaktif pada materi } \\
\text { rekonsiliasi bank sangat layak digunakan } \\
\text { sebagai media alternatif dalam proses } \\
\text { pembelajaran akuntansi. Respon siswa } \\
\text { terhadap media pembelajaran akuntansi } \\
\text { berbasis multimedia interaktif pada materi } \\
\text { rekonsiliasi bank menunjukkan hasil yang } \\
\text { sangat baik, terbukti dari angket respon } \\
\text { siswa yang diberikan. }\end{array}$ \\
\hline 5 & $\begin{array}{l}\text { Lubis dan } \\
\text { Elvianti (2018) }\end{array}$ & $\begin{array}{l}\text { Pengembangan Media Pembelajaran } \\
\text { Akuntansi Berbasis Android Dengan } \\
\text { Aplikasi "Aksi (Asah Akuntansi)" }\end{array}$ & $\begin{array}{l}\text { Berdasarkan penilaian ahli materi dan ahli } \\
\text { media terhadap kelayakan media berbasis } \\
\text { android dengan aplikasi "Asah Akuntansi", } \\
\text { skor rata-rata aspek materi adalah gebesar } \\
4,20 \text { yang dapat dikategorikan "Layak", } \\
\text { aspek media menunjukkan skor rata-rata } \\
4,57 \text { yang dapat dikategorikan "Sangat } \\
\text { Layak". Respons siswa terhadap aplikasi } \\
\text { "Asah Akuntansi" sebagai media } \\
\text { pembelajaran menunjukkan rata-rata } \\
\text { kegeluruhan } 4,27 \text { yang dapat dikategorikan } \\
\text { "Sangat Layak". Dengan demikian aplikasi } \\
\text { "Asah Akuntansi" berbasis android yang } \\
\text { digunakan Layak dijadikan media } \\
\text { pembelajaran akuntansi. }\end{array}$ \\
\hline
\end{tabular}

Sumber: Penelitian Terdahulu, Disusun Peneliti

\section{METODE PENELITIAN}

Pendekatan penelitian ini adalah penelitian eksploratif yang bersifat teknis aplikatif dengan pendekatan multidisipliner yaitu pendekatan bidang ilmu akuntansi dan teknologi. Metode pengumpulan data dalam penelitian ini meliputi dokumentasi, 
observasi, dan wawancara. Desain aplikasi interaktif menggunakan macromedia flash player 8 .

\section{Langkah-langkah penelitian}

Langkah-langkah dalam menyusun penelitian ini adalah sebagai berikut:

\section{Dokumentasi Data Penelitian.}

Dokumentasi data dilakukan dengan mengumpulkan materi pembelajaran kurikulum akuntansi bagi siswa SMK. Hal ini dilakukan dengan cara peneliti mengumpulkan materi dan soal dari buku-buku SMK yang dapat digunakan sebagai content dari aplikasi yang didesain.

\section{Observasi dan Wawancara Data Penelitian}

Setelah peneliti melakukan dokumentasi, maka tahapan selanjutnya adalah peneliti melakukan observasi dan wawancara pada guru akuntansi di SMK. Observasi dan wawancara dilakukan di SMK Barunawati Surabaya. Tujuan dari observasi dan wawancara ini adalah untuk menyesuaikan data dan materi hasil dari dokumentasi dengan materi dan proses belajar mengajar di lapangan. Dengan demikian, diharapkan bahwa aplikasi interaktif yang didesain dapat digunakan dengan baik dalam menunjang proses belajar mengajar di SMK.

\section{Desain Aplikatif Interaktif}

Setelah content yang akan dimasukkan ke dalam aplikasi telah terkumpul, maka tahapan selanjutnya adalah peneliti melakukan desain aplikasi interaktif model pembelajaran akuntansi. Dalam hal desain ini, peneliti bekerjasama dengan pihak lain yang pakar dalam pembuatan software. Materi yang dimasukkan ke dalam aplikasi berasal dari peneliti. Pembuatan aplikasi menggunakan macromedia flash player 8 .

\section{PEMBAHASAN}

Dari hasil dari dokumentasi, observasi dan wawancara, maka peneliti dapat membuat sebuah aplikasi interaktif model pembelajaran akuntansi bagi siswa SMK. Aplikasi tersebut bernama Accounters. Accounters memiliki dua username yaitu 
username bagi guru dan username bagi siswa. Dengan adanya dua username ini, maka baik guru maupun siswa dapat menggunakan aplikasi ini pada saat proses belajar mengajar di kelas sehingga kelas dapat lebih interaktif dan materi pembelajaran lebih mudah dipahami.

Perbedaan dari username guru dan siswa terdapat pada contoh soal yang ada di materi aplikasi. Jika username guru, maka contoh soal tersebut terdapat jawaban soal. Sedangkan bagi username siswa, contoh soal tidak terdapat jawaban soal. Hal ini bertujuan agar siswa dapat membahas dan mencari jawaban dari soal yang diberikan dalam aplikasi Accounters.

Materi pembelajaran pada aplikasi ini terdiri dari pemahaman dasar mengenai akuntansi sampai dengan penyusunan laporan keuangan perusahaan. Aplikasi ini dapat digunakan bagi siswa kelas $\mathrm{X}$ dan XI sehingga dapat dengan lebih mudah dan lebih interaktif dalam memahami dasar-dasar akuntansi. Aplikasi ini juga dapat mengubah sistem pembelajaran guru yang manual menjadi dengan menggunakan sebuah aplikasi atau software.

Sebelum peneliti membuat aplikasi interaktif ini, maka peneliti mengumpulkan materi atau bahan apa saja yang akan dimasukkan ke dalam aplikasi. Untuk menu Materi, maka peneliti mengumpulkan pembahasan dan teori mengenai dasar-dasar akuntansi serta soal/kasus yang dapat digunakan sebagai latihan soal dalam pembelajaran akuntansi bagi siswa SMK. Untuk menu Quiz, maka peneliti mengumpulkan soal-soal pilihan ganda beserta waktu (timer) untuk pengerjaannya yang ditujukan bagi siswa SMK. Menu ini dapat digunakan oleh guru pengajar sebagai media pengambilan nilai tes atau kuis bagi siswanya. Untuk menu Hangman, maka peneliti mengumpulkan kata atau istilah dalam bidang ekonomi dan akuntansi yang digunakan sebagai permainan tebak kata. Menu ini dapat digunakan sebagai sarana refreshing atau jeda di saat proses belajar-mengajar di kelas.

Setelah semua materi atau bahan yang diperlukan terkumpul, maka peneliti memulai proses pendesainan aplikasi interaktif tersebut. Pendesainan aplikasi dibuat semenarik mungkin, eye chatching, dan audio yang mendukung dalam aplikasi tersebut. Mengingat bahwa pengguna/user dari aplikasi ini adalah siswa SMK. Peneliti 
bekerjasama dengan pihak lain yang memiliki kemampuan dalam mendesain aplikasi interaktif/software. Diskusi yang intens selalu dilakukan untuk dapat menghasilkan desain aplikasi Accounters yang sempurna dan dapat diimplementasikan sebagai model pembelajaranakuntansi yang interaktif bagi siswa SMK.

Berikut tampilan utama dari aplikasi Accounters:

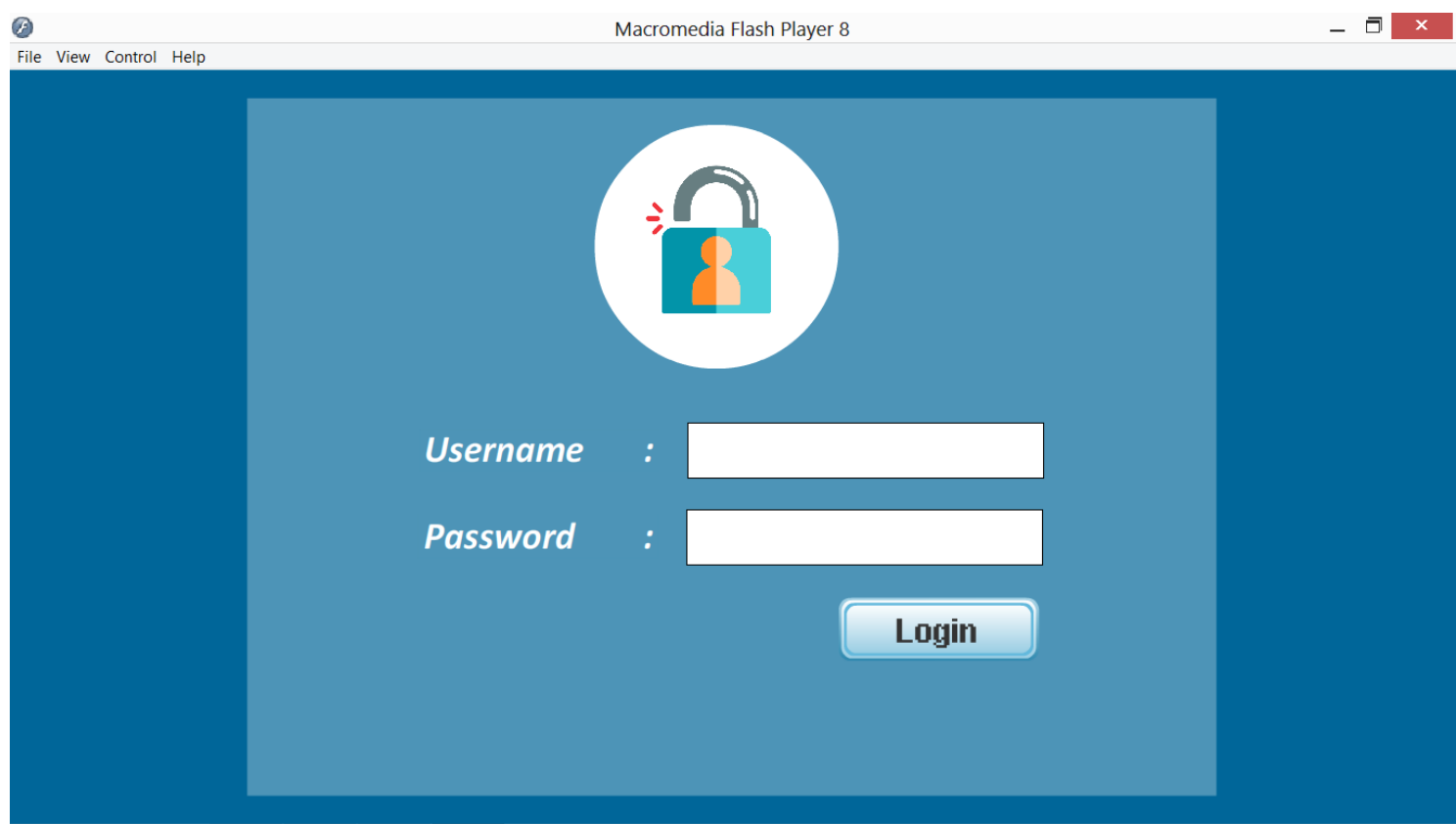

Gambar 1. Tampilan Utama pada Accounters

Dari gambar di atas dapat dilihat bahwa untuk masuk dalam aplikasi tersebut wajib memasukan username dan password. Aplikasi ini dapat menggunakan dua username dan password yaitu username guru dan username siswa.

Berikut tampilan menu dalam Accounters: 

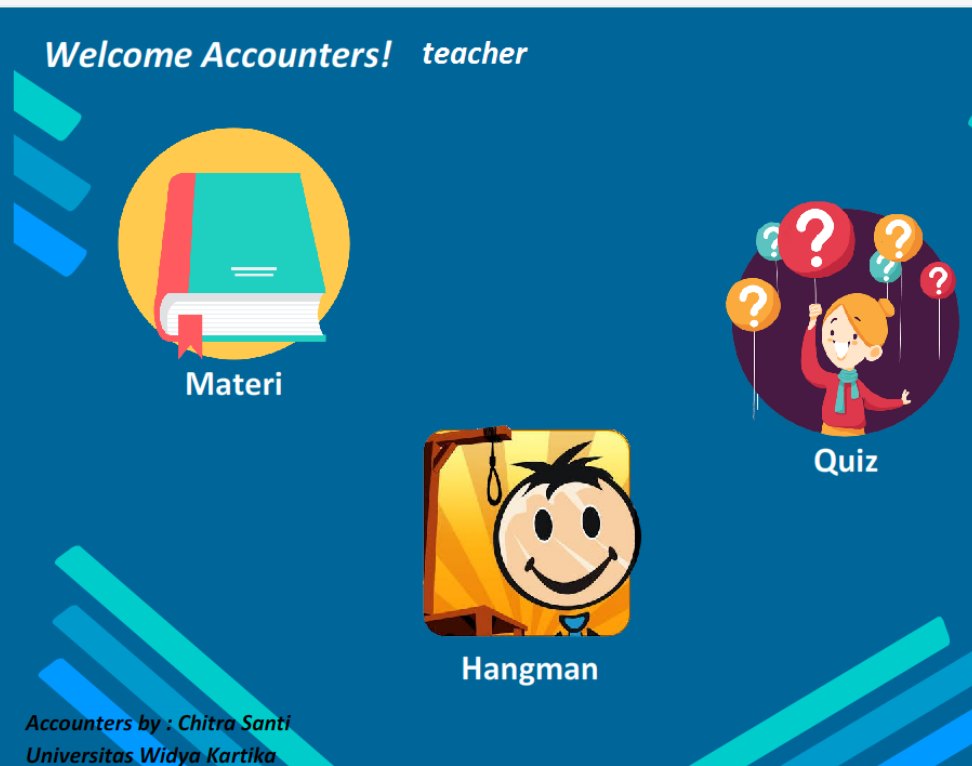

Hangman
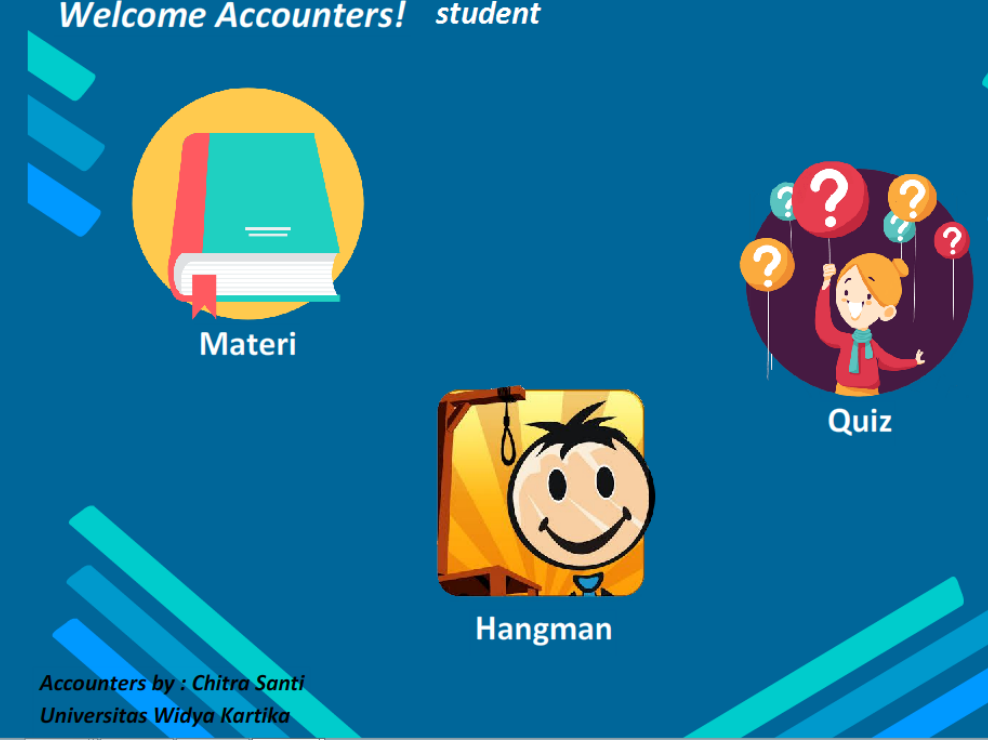

Gambar 2. Tampilan Menu dalam Accounters dengan masing-masing Username

Dari gambar tersebut dapat dilihat bahwa terdapat tiga menu dalam aplikasi tersebu. Pertama, Materi yang berisi materi dasar akuntansi, contoh soal sampai dengan penyusunan laporan keuangan perusahaan. Kedua, Quiz yang berisi soal pilihan ganda atau test yang dapat digunakan guru untuk menilai kemampuan siswa dalam memahami 
materi pembelajaran yang telah diberikan. Terdapat waktu yang berjalan dalam pengerjaan test tersebut. Ketiga, Hangman yang berisi permainan tebak kata mengenai istilah dalam akuntansi dan ekonomi yang dapat dilakukan disela-sela proses belajarmengajar.

Tampilan dari menu Materi dapat dilihat dalam gambar berikut ini:

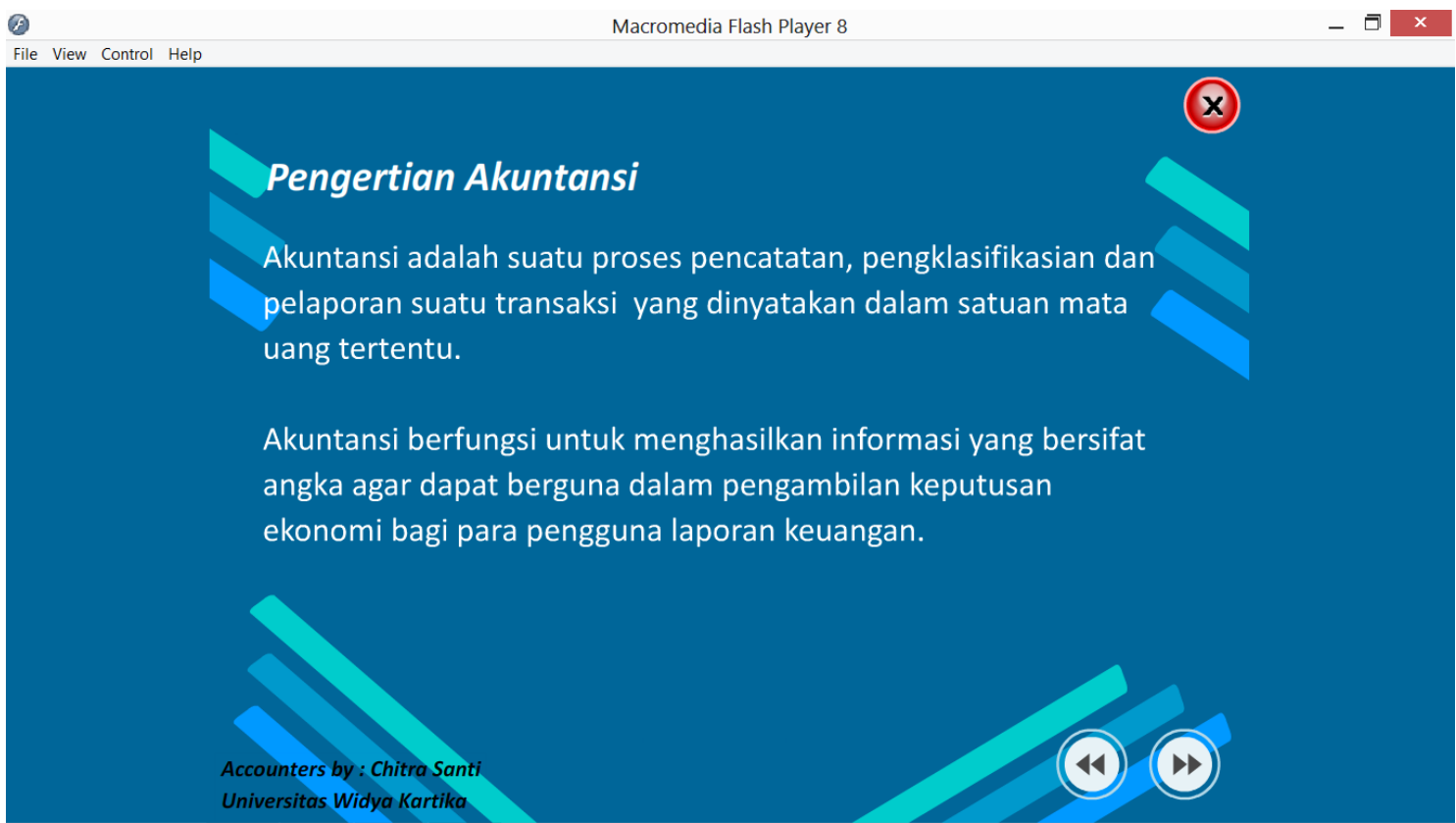

Gambar 3. Tampilan Menu Materi dalam Accounters

Tampilan dari menu Quiz dapat dilihat dalam gambar berikut ini:

공

Macromedia Flash Player 8

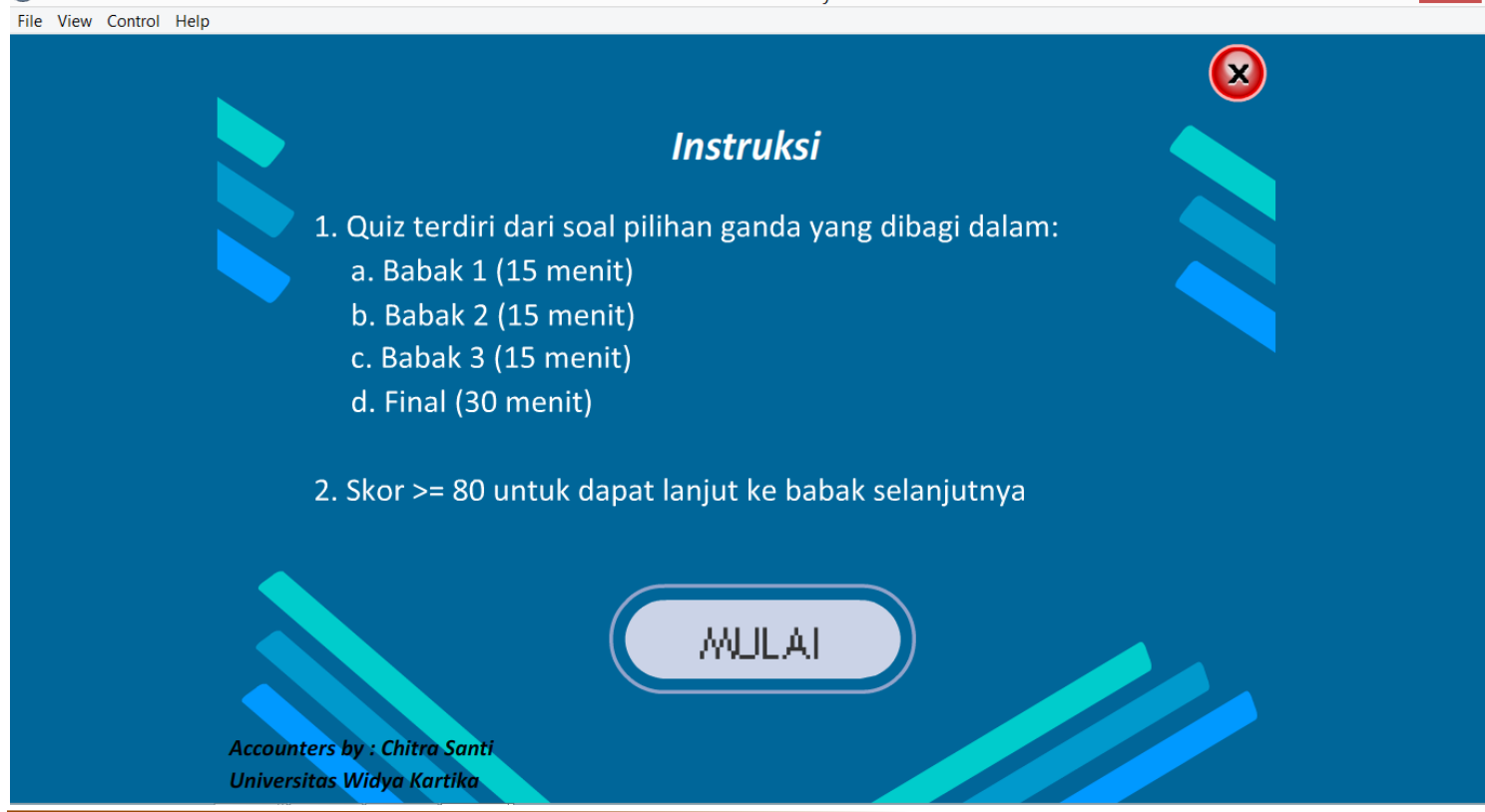

J-MACC : Journal of Management and Accounting 
(6)

Macromedia Flash Player 8

1 Dibeli perlengkapan salon dari toko sumber waras dengan kredit. Analisis transaksi tersebut adalah...

A Harta bertambah, yaitu perlengkapan salon; utang bertambah

B Harta bertambah, yaitu perlengkapan salon; utang berkurang

c Harta bertambah, yaitu perlengkapan salon; kas berkurang

D Harta berkurang, yaitu perlengkapan salon; kas bertambah

Perlengkapan salon bertambah dan beban perlengkapan salon bertambah

Gambar 4. Tampilan Menu Quiz dalam Accounters

Tampilan dari menu Hangman dapat dilihat dalam gambar berikut ini:

(2)

Macromedia Flash Player 8

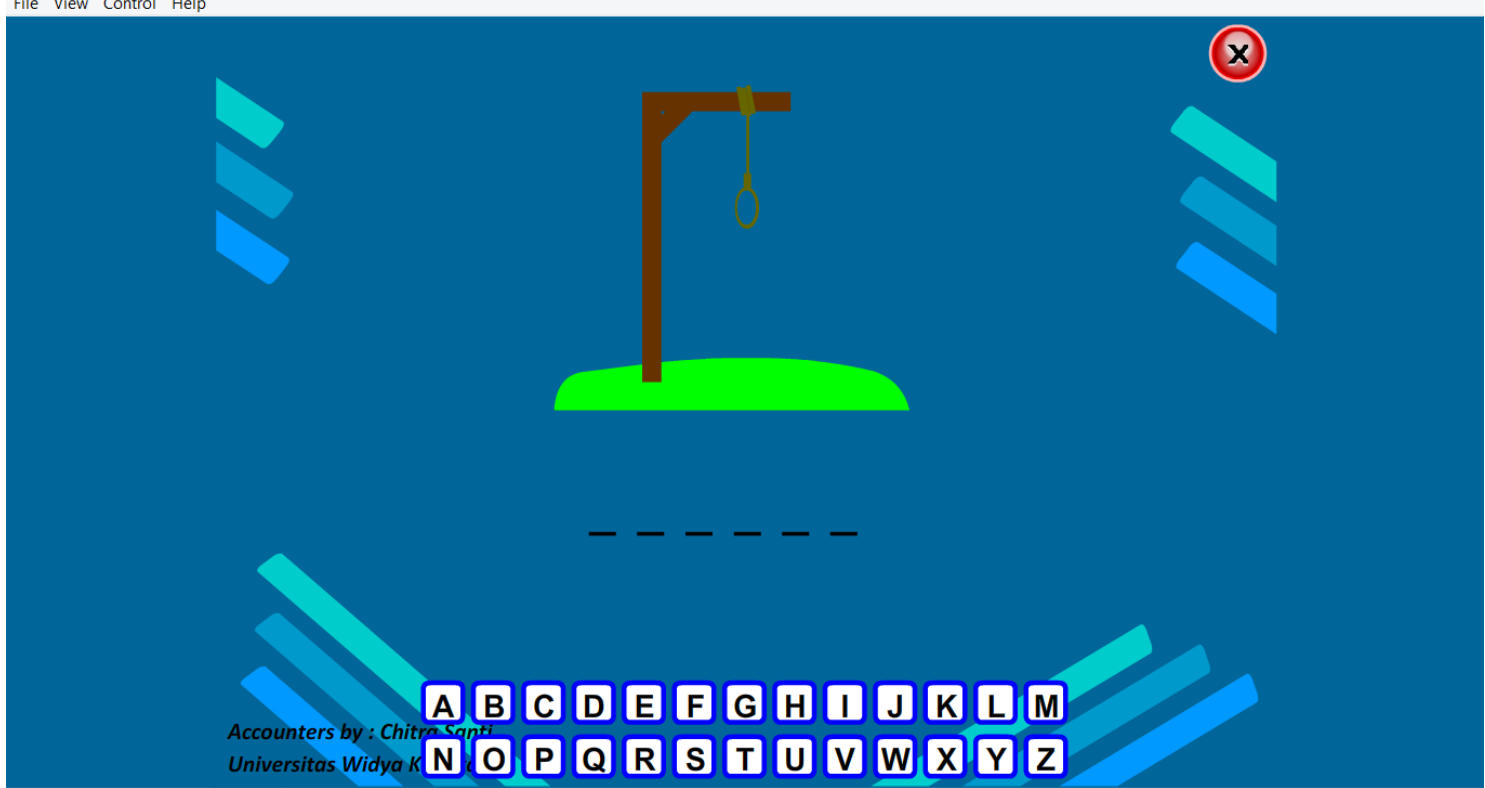

J-MACC : Journal of Management and Accounting 
(B)

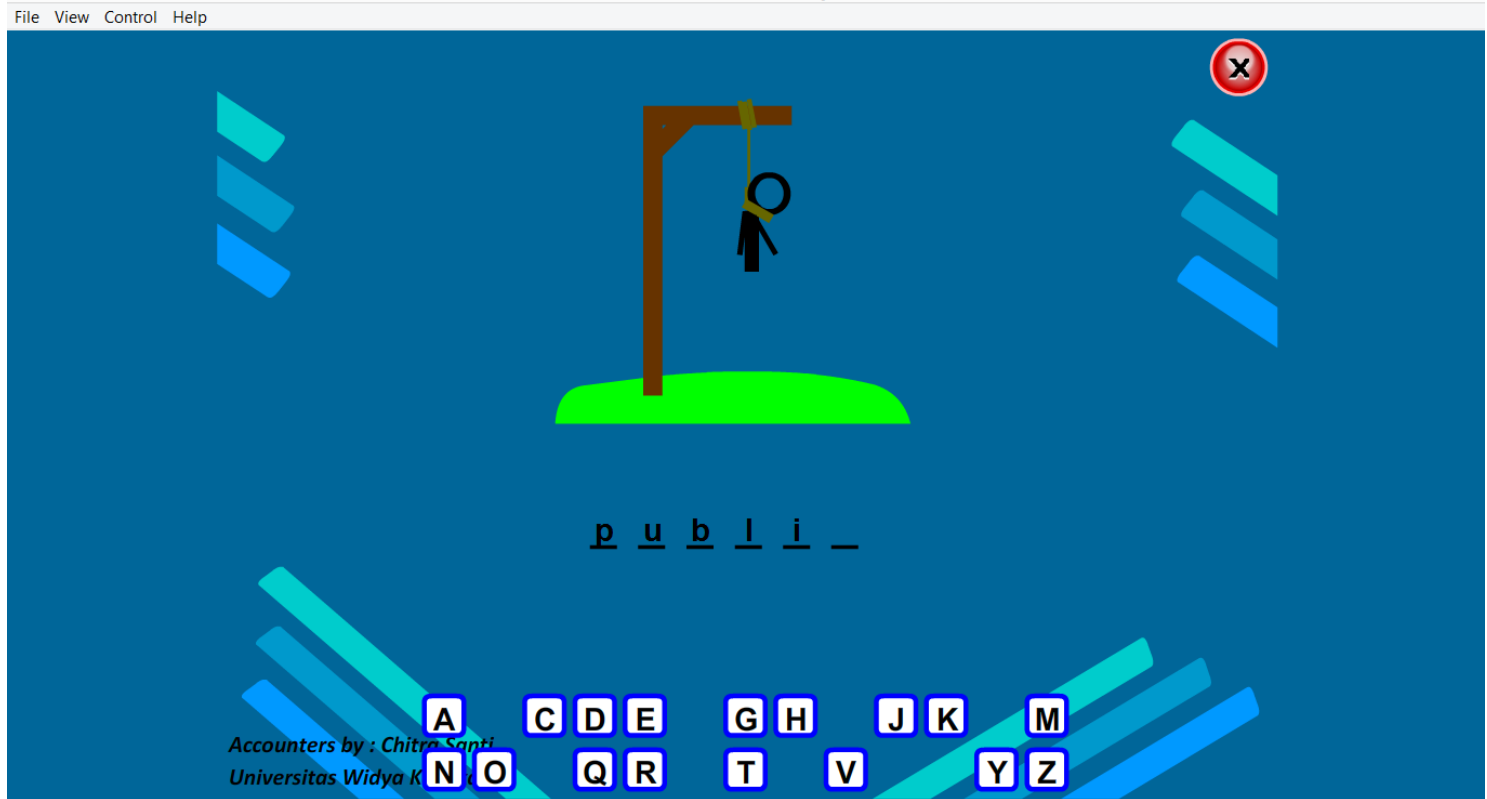

Gambar 5. Tampilan Menu Hangman dalam Accounters

Penelitian ini bertujuan untuk pengembangan model pembelajaran akuntansi dengan aplikasi interaktif untuk meningkatkan kemampuan dan motivasi siswa pada Sekolah Menengah Kejuruan. Implementasi aplikasi interaktif Accounters sebagai media pembelajaran akuntansi diharapkan dapat meningkatkan motivasi belajar siswa dalam bidang ilmu akuntansi. Diharapkan dengan adanya Media Pembelajaran Akuntansi Menggunakan Aplikasi Accounters ini yang lebih mudah dan cepat untuk mempelajari ilmu akuntansi secara efektif. Untuk mengetahui dampak dan manfaat dari penggunaan aplikasi interaktif ini, maka diperlukan penelitian lebih lanjut yang akan dilaksanakan oleh peneliti kedepannya.

\section{SIMPULAN DAN SARAN}

Penelitian ini bertujuan untuk mendesain model pembelajaran akuntansi berbasis teknologi untuk mempermudah dan memotivasi belajar akuntansi bagi siswa SMK.Hasil penelitian memberikan sebuah aplikasi interaktif model pembelajaran akuntansi yang dinamakan Accounters. Aplikasi ini terdiri dari tiga menu utama yaitu Materi, Quiz, dan Hangman (permainan). Oleh karena itu, dengan aplikasi Accounters ini mempermudah siswa di SMK untuk lebih memahami tentang akuntansi, sehingga mampu membuat laporan keuangan bagi Perusahan saat mereka bekerja nantinya. Serta mampu meningkatkan motivasi belajar siswa dalam bidang ilmu akuntansi. 
Hasil penelitian ini diharapkan dapat memberi pandangan bagi guru pengajar Akuntansi di SMK bahwa metode pembelajaran yang tradisional sudah mulai bergeser dengan menggunakan aplikasi interaktif. Aplikasi Accounters ini dapat digunakan sebagai pendukung dalam proses belajar-mengajar di kelas sehingga dapat meningkatkan motivasi dari siswa dalam belajar.

Penelitian ini memiliki keterbatasan yaitu aplikasi interaktif yang dikembangkan oleh peneliti belum diujicobakan penggunaannya secara intens di SMK. Dengan demikian belum terdapat feedback dari pengguna aplikasi Accounters mengenai kelebihan dan kekurangan aplikasi ini.

Ucapan Terima Kasih Peneliti sampaikan kepada Kemenristekdikti yang telah memberi dana dalam proses penelitian ini melalui skema Penelitian Dosen Pemula 2019.

\section{DAFTAR PUSTAKA}

B uno, Hamzah.2006.Orientasi Baru dalam Psikologi Pembelajaran.Jakarta: PT Bumi Aksara

Daryanto. 2010. Media Pembelajaran. Yogyakarta: Gava Media.

Reeve, J.M., Warren, C.S., \& Duchec, J.E. 2013. Pengantar Akuntansi. Jakarta: Salemba Empat.

Sanjaya, Wina. 2008. Perencanaan dan Desain Sistem Pembelajaran. Jakarta: Kencana Prenada Media Group.

Sutikno, Sobry. 2013. Belajar Dan Pembelajaran, Upaya Kreatif Dalam Mewujudkan belajar dan Pembelajaran. Lombok: Holistica.

Seel dan Richey. 2014. Instructional Technology. AECT. Washington, DC

Slavin, Robert E. 2011. Cooperative Learning Teori, Riset dan Praktik. Bandung: Nusa Media.

Titisari et al. 2013. Model Pembelajaran Akuntansi Untuk Meningkatkan Kompetensi Mahasiswa. Jurnal Buletin Studi Ekonomi, Vol. 18, No. 2, Agustus 2013. https://www.accountingtools.com/articles/2017/5/10/financial-statements 